\title{
Pengaruh Kompetensi Paedagogik Guru Terhadap Prestasi Belajar Siswa Kelas XI Mata Pelajaran PAI Di SMKN 13 Malang Subhan Adi Santoso
}

\section{Dosen Sekolah Tinggi Ilmu Tarbiyah Muhammadiyah Paciran Lamongan}

Email: $H$ ans84@yahoo.co.id

Abstract: Pedagogic competence is the ability to manage student learning which includes students 'understanding, design and implementation of learning, evaluation of learning outcomes, and development of students to develop various potentials of students, while learning achievement is the aspect of the students' skills as a result of business and learning activities pursued, Is seen as an important indicator in the overall process of education in general and the process of teaching and learning in particular. The method used in data collection is descriptive method. While the approach taken is a quantitative approach. Data collection in this study includes literature study and field study. The implementation of this field study involves observation techniques, interviews, and using data collection instruments in the form of questionnaires. The average score of teacher paedagogic competency variables (Variable $X$ ) has an average of 2.49, the scores in the assessment criteria are at 2.5-3.5 intervals with medium qualifications and for the average grade of learning achievement Students (Variable Y) that has an average value of 3.67 numbers in the scale of the assessment is at the interval of 3.5-4.5 with high qualification. Based on data analysis there is a significant relationship between teacher Paedagogic Competence on student achievement. The magnitude of the effect of variable $X$ to $Y$ is 0.86 . The contribution of variable $X$ to $Y$ is $49 \%$ and the remaining $51 \%$ is influenced by other factors .. This information provides information that the teacher paedagogic competence variables have a strong influence on student achievement that is Based on the above calculation known that the value of $Z$ arithmetic 4.3> Z table 0.01 then the hypothesis (Ho) rejected and (Ha) accepted, this means the influence between variable $X$ and variable $Y$ with significant influence.

Key word: Master's Paedagogic Competencies, Student Achievement

Pendidikan adalah "pengaruh, bantuan atau tuntutan yang diberikan oleh orang yang bertanggungjawab kepada anak didik. (Abu Ahmadi dan Nur Uhbiyati, 2001, p.71) Pendidikan merupakan kegiatan yang universal dalam kehidupan manusia, dan merupakan aspek terpenting untuk kehidupan manusia, karena dengan adanya pendidikan dapat menciptakan perubahan sikap yang baik pada diri seseorang.

Penyelenggaraan pendidikan tidak dapat dilepaskan dari tujuan pendidikan yang hendak dicapainya. Hal ini dibuktikan dengan penyelenggaraan pendidikan yang ada di Indonesia. Dalam undang-undang RI NO 20 tahun 2003, tentang sistem pendidikan nasional dikemukakan bahwa pendidikan nasional bertujuan untuk "membangkitkan potensi peserta didik agar menjadi manusia yang beriman 
dan berakhlak mulia, sehat, berilmu, cakap, kreatif, mandiri dan menjadi warga negara yang demokratis serta bertanggung jawab dalam rangka mencerdaskan kehidupan bangsa. (Undang-undang RI no 20 tahun 2003, Sistem Pendidikan Nasional, diakses 11 April 2016)

Tujuan pendidikan tersebut telah digariskan dalam pembukaan UUD 1945 pada alinea ke empat yaitu "mencerdaskan kehidupan bangsa". Untuk merealisasikan tujuan tersebut, pemerintah telah menerapkan empat strategi pokok pembangunan pendidikan nasional, yaitu peningkatan pemerataan kesempatan pendidikan, relevansi pendidikan dengan pembangunan, kualitas pendidikan dan efisiensi pengelolaan pendidikan. Dengan menerapkan empat strategi pokok tersebut diharapkan agar kualitas dan mutu pendidikan di negara kita dapat ditingkatkan sehingga menghasilkan output yang berkualitas dan dapat diandalkan.

Menurut W.H. Burton yang dikutip oleh Uzer Usman bahwa belajar diartikan "sebagai perubahan tingkah laku pada diri individu berkat adanya interaksi antara individu dengan individu dan individu dengan lingkungannya . Sedangkan mengajar merupakan "suatu usaha mengorganisasikan lingkungan dalam hubungannya dengan anak didik. (Usman, 1995, p.2)

Mengajar ditingkat pendidikan formal biasanya dilakukan oleh seorang guru. Menurut Darji Darmodiharjo seperti yang dikutip oleh Marno menyatakan bahwa :

"Minimal ada tiga tugas sebagai penjabaran dari misi dan fungsi yang diembannya, diantaranya : mendidik, mengajar dan melatih. Tugas mendidik lebih menekankan pada pembentukkan jiwa, karakter, dan kepribadian berdasarkan nilai-nilai. Tugas mengajar lebih menekankan pada pengembangan kemampuan penalaran dan tugas melatih menekankan pada pengembangan kemampuan penerapan teknologi dengan cara melatih berbagai keterampilan". (Marno, 2008, p.87)

Dalam perspektif Islam, mengemban amanat sebagai guru bukan terbatas pada pekerjaan atau jabatan seseorang, melainkan memiliki dimensi nilai yang lebih luas dan agung, yaitu tugas ketuhanan, kerasulan dan kemanusiaan. Dikatakan sebagai tugas ketuhanan, karena mendidik merupakan sifat "fungsional"Allah (Sifat rububiyah) sebagai "rabb" yaitu sebagai "guru" bagi semua makhluk. Allah mengajar semua makhluknya lewat tanda-tanda alam (sign), dengan menurunkan wahyu, mengutus rasul-Nya, dan lewat hambahamba-Nya. Allah memanggil hamba-hamba-Nya yang beriman untuk mendidik. Guru yang mampu melaksanakan peranannya dengan baik disebut sebagai guru yang memiliki kompetensi. Salah satu kompetensi utama yang harus dimiliki seorang guru adalah kompetensi paedagogik.

Kompetensi paedagogik merupakan salah satu kompetensi yang harus dimiliki guru. Kompetensi paedagogik adalah kemampuan mengelola pembelajaran siswa yang meliputi pemahaman siswa, perancangan dan pelaksanaan pembelajaran, evaluasi hasil belajar, dan pengembangan siswa untuk 
mengembangkan berbagai potensi yang dimiliki siswa. Menurut Standart Nasional Pendidikan pasal 28 ayat (3) kompetensi pedagogik yaitu "kemampuan mengelola pembelajaran siswa yang meliputi pemahaman siswa, perancangan dan pelaksanaan pembelajaran, evaluasi hasil belajar, dan pengembangan siswa untuk mengaktualisasikan berbagai potensi yang dimilikinya. (Standart Nasional Pendidikan pasal 28 ayat 3, diakses 11 April 2016)

Kompetensi paedagogik guru sangat berpengaruh terhadap prestasi belajar siswa. Hal ini dapat dijelaskan bahwa semakin tinggi kompetensi paedagogik guru maka semakin tinggi pula hasil yang dicapai oleh siswa. Hal ini dikarenakan bahwa keberhasilan pembelajaran di dalam kelas ditentukan oleh kompetensi pedagogik yang dimiliki oleh guru. Keberhasilan pembelajaran di dalam kelas dapat ditandai dengan tingginya nilai yang dicapai siswa, dalam hal ini yakni prestasi belajar siswa.

Kompetensi paedagogik sangat penting untuk mendukung pembelajaran. Tanpa adanya kompetensi paedagogik maka guru akan mengalami kesulitan dalam melaksanakan pembelajaran di sekolah. Terutama sekali untuk guru mata pelajaran Al-Qur'an Hadits yang memfokuskan pada pemahaman tentang baca tulis Al-Qur'an dan Hadits secara baik dan benar, sehingga tidak dapat dilakukan dengan baik oleh seorang guru tanpa persiapan.

Hasil pengalaman penulis selama menempuh ditingkat SMP maupun ditingkat SMA dan pengamatan dilapangan menunjukan bahwa kenyataannya di lapangan, ketika mengajar pada mata pelajaran Al-Qur'an Hadits banyak atau beberapa guru kurang memperhatikan strategi pembelajaran yang digunakannya. Mengingat pentingnya kompetensi paedagogik guru mata pelajaran Al-Qur'an Hadits, maka guru diharapkan dapat meningkatkan kemampuan mengajar terhadap peserta didiknya terhadap mata pelajaran tersebut.

Berdasarkan permasalahan diatas, maka penulis ingin mengkajinya dengan judul penelitian "Pengaruh Kompetensi Paedagogik Guru Terhadap Prestasi Belajar Siswa Kelas XI Mata Pelajaran PAI Di SMKN 13 Malang”.

Berdasarkan latar belakang masalah diatas, maka rumusan rumusan masalah sebagai berikut: Bagaimana pengaruh kompetensi pedagogik guru terhadap prestasi belajar siswa kelas XI mata pelajaran PAI di SMKN 13 Malang dan Bagaimanana prestasi belajar siswa kelas XI mata pelajaran PAI di SMKN 13 Malang?

\section{Kajian Teori}

\section{Pengertian Kompetensi Paedagogik Guru}

Paedagogik berasal dari kata Yunani "paedagogiek, kata turunan dari perkataan paedagogia yang berarti "pergaulan dengan anak-anak". Paedagogia berasal dari kata "paedos/paes", yang berarti anak, dan "agogos/ago" yang berarti mengantar atau membimbing. Dari kata paedagogos lahir dari kata paedagoog (bahasa belanda), yang artinya pendidik atau ahli didik. Secara kiasan pedagogik diartikan sebagai "seorang ahli yang membimbing anak ke arah tujuan hidup tertentu. (Sri Hendrawati, 2010, p.1) 
Secara istilah paedagogik itu adalah "ilmu pendidikan atau ilmu mendidik, yang berarti ilmu pengetahuan yang menyelidiki, merenungkan tentang gejalagejala perbuatan mendidik. (Ngalim Purwanto, 1995, p.3) Guru sebaiknya memahami paedagogik hingga dapat mengemban amanah dalam membelajarkan peserta didik dengan langkah dan cara yang tepat sesuai dengan kebutuhan dan karakteristik peserta didik.

\section{Indikator Kompetensi Paedagogik Guru}

Adapun indikator kompetensi paedagogik guru diantaranya :

1. Menguasai Karakteristik Peserta Didik

2. Menguasai Teori dan Prinsip-prinsip pembelajaran

3. Mengembangkan Kurikulum/Rancangan Pembelajaran

4. Menyelenggarakan pembelajaran yang mendidik

5. Memahami TIK untuk kepentingan pembelajaran. (Dimyati dan Mudjiono, 2006, p.7)

\section{Faktor-faktor yang Mempengaruhi Kompetensi Paedagogik Guru}

Menurut Sahertian mengatakan bahwa faktor-faktor yang mempengaruhi kompetensi paedagogik guru adalah :

1. Pengetahuan, keterampilan dan sikap yang dimiliki guru

2. Kepemimpinan Kepala Sekolah

3. Lingkungan kerja yang mendorong motivasi kerja guru untuk meningkatkan pengetahuan, keterampilan, dan sikap dalam pelaksanaan tugas secara optimal.

\section{Pengertian Prestasi Belajar}

Menurut WJS Poerwadarminta berpendapat, bahwa prestasi adalah hasil yang telah dicapai (dilakukan, dikerjakan dan sebagainya). (WJS Poerwadarminta, 1982, p.773) Sedangkan menurut Mas'ud Khasan Abdul Qahar, prestasi adalah apa yang telah dapat diciptakan, hasil pekerjaan, hasil yang menyenangkan hati yang diperoleh dengan jalan keuletan bekerja.(Syaiful Bahri Djamarah, 1994, p. 21) Sedangkan menurut Bloom prestasi belajar adalah proses belajar yang dialami siswa dan menghasilkan perubahan dalam bidang pengetahuan, pemahaman, penerapan, daya analisis, sintesis dan evaluasi.(Reni Kbar Hawadi, 2004, p.68)

Dari beberapa pengertian prestasi yang dikemukakan para ahli di atas, jelas terlihat perbedaan pada kata-kata tertentu sebagai penekanan, namun intinya sama, yakni hasil yang dicapai dari suatu kegiatan. Untuk itu dapat difahami bahwa prestasi adalah hasil dari suatu kegiatan yang telah dikerjakan, diciptakan, yang menyenangkan hati yang diperoleh dengan jalan keuletan kerja, baik secara individual maupun kelompok dalam bidang kegiatan tertentu. 
Jadi prestasi belajar adalah hasil yang diperoleh berupa kesan-kesan yang mengakibatkan perubahan dalam diri individu maupun kelompok sebagai hasil dari aktifitas dalam belajar.

Surya menyatakan bahwa pengertian dari belajar adalah suatu proses yang dilakukan individu untuk memperoleh suatu perubahan tingkah laku yang baru secara keseluruhan, sebagai hasil dari pengalaman individu itu sendiri dalam interaksi dengan lingkungannya.( Tohirin, 2005, p.8) Dan dalam bukunya ANITA WOOLFOLK menjelaskan bahwa learning is process through which experience causes permanent change in knowledge or behavior.( Anita Woolfolk, 2004, p.198)

Secara umum belajar dapat diartikan sebagai suatu perubahan tingkah laku yang relatif menetap terjadi sebagai hasil dari pengalaman atau tingkah laku. Yang dimaksud dengan pengalaman adalah segala kejadian yang secara sengaja dialami oleh setiap orang. Sedangkan latihan merupakan kejadian yang dengan sengaja dilakukan setiap orang secara berulang-ulang. (Muhaimin, Abd Ghofir, Nur Ali Rahman, 1996, p.43)

\section{Macam-macam Prestasi Belajar}

Adapun macam-macam prestasi belajar antara lain;

a. Prestasi yang bersifat kognitif

Yang termasuk dalam prestasi yang bersifat kognitif yaitu; ingatan, pemahaman, penerapan, pengamatan, analisis, sintesis dan lain-lain. Misalnya seorang siswa mampu menyebutkan materi pelajaran yang sudah dipelajari pada minggu lalu maka siswa tersebut bisa dikatakan potensi dalam kognitifnya dan lain sebagainya.

b. Prestasi yang bersifat afektif

Yang termasuk dalam prestasi afektif adalah yaitu sikap menghargai, penerimaan, penolakan dan lain-lain. Misalnya seorang siswa dapat menunjukkan sikap menerima dan menolak terhadap sustu pernyataan atau suatu permasalahan dan lain-lain. Itu bisa dikatakan bahwa siswa mengalami prestasi afektif.

c. Prestasi yang bersifat psikomotorik

Yang termasuk prestasi yang bersifat psikomorik siswa yaitu; kecakapan ekspresi verbal dan non verbal, ketrampilan bergerak dan bertindak. Misalnya seorang siswa menerima tentang adab sopan santun kepada orangtua, maka si anak mengaplikasikan pelajaran tersebut ke dalam kehidupan sehari-hari. (Muhibbin Syah, 2006, p.154) 


\section{Faktor-faktor yang Mempengaruhi Prestasi Belajar}

Faktor-faktor psikologis yang mempengaruhi belajar, termasuk kedalam faktor internal, yakni faktor dari diri dalam siswa. Faktor ini terdiri dari dua aspek antara lain:

Aspek Fisiologis

Aspek fisiologis yang mempengaruhi belajar berkenaan dengan keadaan dengan keadaan dan kondisi umum jasmani seseorang, misalnya menyangkut kesehatan atau kondisi tubuh, seperti sakit atau terjadinya gangguan pada fungsi-fungsi tubuh. Aspek ini juga menyangkut kebugaran tubuh. Tubuh yang kurang prima, akan mengalami kesulitan belajar. Untuk menjaga kondisi tubuh, dianjurkan untuk menjaga atau mengatur pola istirahat yang baik dan mengatur menu makanan atau mengonsumsi makanan yang sehat dan bergizi. (Muhibbin Syah, 2006, p.127) Aspek Psikologis

Proses belajar merupakan hal yang kompleks. Siswalah yang menentukan terjadi dan tidak terjadinya belajar. Untuk bertindak belajar siswa menghadapi masalah-masalah secara intern. Jika siswa tidak dapat mengatasi masalahnya, maka ia tidak belajar dengan baik. (Dimyati, Mudjiono, 1997, p.238)

Faktor eksternal siswa juga terdiri atas tiga macam yakni:

Lingkungan sosial

Lingkungan sosial sekolah seperti para guru, para staf administrasi dan teman-teman sekelas dapat mempengaruhi semangat belajar seorang siswa. Para guru yang selalu menunjukkan sikap dari prilaku yang simpatik dan memperlihatkan suri teladan yang baik dan rajin khususnya dalam hal belajar, misalnya rajin belajar dan berdiskusi, dapat menjadi daya dorong yang positif bagi kegiatan belajar siswa.( Dimyati, Mudjiono, 1997, p.137)

\section{Lingkungan non-sosial}

Faktor-faktor yang termasuk lingkungan non-sosial ialah gedung sekolah dan letaknya, rumah tempat tinggal keluarga siswa dan letaknya, 
alat-alat belajar, keadaan cuaca dan waktu belajar yang digunakan siswa. Factor-faktor ini turut menentukan tingkat keberhasilan belajar siswa.

(Dimyati, Mudjiono, 1997, p.138)

Pendekatan belajar siswa.

Faktor pendekatan belajar adalah upaya belajar siswa yang meliputi strategi dan metode yang digunakan siswa untuk melakukan kegiatan pembelajaran materi-materi pelajaran. (Dimyati, Mudjiono, 1997, p.133)

\section{Metode Penelitian \\ Rancangan Penelitian}

Penelitian ini merupakan penelitian kuantitatif deskriptif korelasional, dimana penelitian kuantitatif adalah suatu proses menemukan pengetahuan yang menggunakan data berupa angka sebagai alat menemukan keterangan mengenai apa yang ingin diketahui peneliti. Angka-angka yang terkumpul sebagai hasil penelitian kemudian dapat dianalisis menggunakan metode statistik. (Margono, 2000, p.103) Sedangkan jenis penelitiannya berupa korelasi yang bertujuan untuk menemukan ada tidaknya hubungan antara dua variabel, dan apabila ada seberapa erat hubungannya. (Suharsimi Arikunto, 2005, p.247)

\section{Variabel Penelitian}

Dalam penelitian kuantitatif, variabel mempunya ciri-ciri tertentu. Menurut purwanto variabel mempunyai tiga ciri, yaitu: dapat diukur, membedakan satu objek dari objek yang lain dalam satu populasi, dan nilainya bervariasi. (Purwanto, 2007, p.45) Djunaidi juga mengatakan bahwa dalam penelitian pendidikan hubungan antara variabel adalah bersifat multivariate, dengan kata lain hubungan deterministis antara satu variabel bebas dengan satu variabel lain yang tidak bebas ada dan selalu terjadi. (Djunaidi Ghoni, 2009, p.119) Maka dapat ditentukan beberapa variabel sebagai berikut:

1. Variabel bebas (independent variable) atau variabel $\mathrm{X}$ adalah variabel yang dipandang sebagai penyebab munculnya variabel terikat yang diduga sebagai akibatnya.

2. Variabel terikat (dependent variable) atau variabel $Y$ adalah variabel (akibat) yang dipradugakan, yang bervariasi mengikuti perubahan dari variabel-variabel bebas. Umumnya merupakan kondisi yang ingin kita ungkap dan jelaskan.

Adapun variabel yang hendak diteliti adalah:

1. Variabel bebas (X) : Pengaruh Kompetensi Paedagogik Guru

2. Variabel terikat (Y) : Prestasi belajar siswa 


\section{Populasi dan Sampel}

Diantara langkah awal dalam penelitian ini adalah dengan menentukan:

\section{Populasi}

Menurut Suharsimi Arikunto, populasi adalah keseluruhan subyek penelitian apabila seseorang ingin meneliti semua subyek, maka penelitian tersebut merupakan penelitian populasi. Sedangkan menurut Bambang Soepono populasi adalah keseluruhan subyek/obyek yang menjadi sasaran penelitian. Dan menurut Ibnu Hajar, populasi adalah kelompok besar individu yang mempunyai karakteristik umum sama.

Dari para pendapat diatas dapat disimpulkan bahwa populasi adalah keseluruhan subyek obyek yang memiliki karakteristik umum sama. Adapun yang menjadi populasi dalam penelitian ini adalah siswa kelas XI mata pelajaran PAI di SMKN 13 Malang yang berjumlah 40 siswa.

\section{Sampel}

Menurut Suharsimi Arikunto sampel adalah sebagian atau wakil populasi yang diteliti. Sedangkan menurut Bambang Soepono sampel adalah bagian populasi yang masih terwarnai oleh sifat dan karakteristik populasi untuk dikenakan penelitian ini.

Menurut Soemanto sampel adalah sebagian subyek yang dipilih dan dianggap mewakili keseluruhan populasi.

Dalam pengambilan sampel, peneliti menggunakan teknik Non random yang jenisnya Purposive Sample (sample bertujuan), yaitu sampel yang dilakukan dengan cara mengambil subyek bukan strata, random ataupun daerah tetapi didasarkan atas tujuan tertentu.

Dalam pengambilan sample menggunakan Purposive Sample ada beberapa syarat-syarat yang harus dipenuhi, yaitu:

a. Pengambilan sampel harus didasarkan atas ciri-ciri, sifat-sifat atau karakteristik tertentu, yang merupakan ciri-ciri pokok populasi.

b. Subyek yang diambil sebagai sampel benar-benar merupakan subyek yang paling banyak mengandung ciri-ciri yang terdapat pada populasi (key subjectis)

c. Penentuan karakteristik populasi dilakukan dengan cermat didalam study pendahuluan.

\section{Metode Pengumpulan Data}

Dalam hal ini metode pengumpulan data yang digunakan adalah metode:

\section{Metode Interview}

Interview adalah metode pengumpulan data dengan jalan Tanya jawab atau wawancara antara peneliti dengan responden untuk memperoleh informasi. Teknik ini dilakukan secara tatap muka. Interview digunakan untuk mengumpulkan data tentang sejarah atau latar belakang berdirinya lembaga serta hal-hal yang kurang jelas dari jawaban angket, sehingga perlu ditanyakan kembali kepada gurunya sebagai pembimbing secara langsung. Wawancara nantinya akan diberikan kepada kepala sekolah, guru dan beberapa siswa. 


\section{Metode angket}

Angket atau questioner adalah metode pengumpulan data melalui sejumlah pertanyaan tertulis yang dipergunakan untuk memperoleh informasi dari responden dalam arti laporan tentang pribadinya, hal-hal yang ia ketahui.

Dalam pelaksanaan penelitian ini dengan membuat daftar pertanyaan yang diberikan kepada respondent disertai alternative jawaban. Dan angket nantinya diajukan kepada siswa untuk memperoleh data tentang Pengaruh Kompetensi Paedagogik Guru dan prestasi belajar siswa.

\section{Metode Dokumentasi}

Dokumentasi adalah cara pengumpulan data mengenai hal-hal berupa benda-benda tertulis seperti buku-buku, majalah, dokumen, peraturan-peraturan notulen rapat, catatan harian, dan sebagainya. Dokumentasi dalam penelitian ini nantinya ditujukan untuk memperoleh data langsung dari tempat penelitian, yang meliputi struktur organisasi, jumlah guru dan karyawan, jumlah siswa, dan segala sesuatu yang mendukung penelitian.

\section{Teknik Analisis Data}

Data-data yang sudah ada (terkumpul), sebelum dianalisis, terlebih dahulu dilakukan pengolahan data. Pengolahan data melalui proses sebagai berikut:

Editing (penyuntingan), yaitu dengan memeriksa seluruh daftar pertanyaan yang dikembangkan respondent.

Koding (pengkodean), yaitu memberi tanda (simbol) yang berupa angket pada jawaban respondent yang diterima.

Tabuling (tabulasi) yaitu menyusun dan menghitung data hasil pengkodean untuk disajikan dalam bentuk tabel.

Setelah pengolahan data lalu dilakukan analisa data untuk membuktikan efektif tidaknya Pengaruh Kompetensi Paedagogik Guru Terhadap Prestasi Belajar Siswa Kelas XI Mata Pelajaran PAI Di SMKN 13 Malang sesuai dengan jenis data pada variabel tersebut, maka penulis menggunakan teknik analisis data sebagai berikut:

\section{Teknik analisa prosentase}

Semua data-data yang berhasil dikumpulkan dari sumber-sumber penelitian akan dibahas oleh penulis dengan menggunakan metode deskriptif analisis, ya itu menjelaskan data-data yang diperolehnya dengan menggunakan perhitungan prosentase atau biasa disebut frekuensi relative.

Untuk memperoleh frekuensi relative digunakan rumus:

$\mathrm{P}=\mathrm{F} / \mathrm{N} \times 100 \%$

Keterangan :

$\mathrm{F} \quad=$ Frekuensi yang sedang dicari prosentasenya

$\mathrm{N} \quad=$ Number of cases (jumlah frekuensi atau banyaknya individu)

$\mathrm{P} \quad=$ Angket prosentase.

Adapun untuk memberikan nilai pada angket, penulis memberikan ketentuan sebagai berikut: 
Untuk score jawaban SS (sangat setuju) dinilai 4

Untuk score jawaban S (setuju) dinilai 3

Untuk score jawaban TS (tidak setuju) dinilai 2

Untuk score jawaban STS (sangat tidak setuju) dinilai 1

Dan untuk menafsirkan hasil perhitungan dengan prosentase penelitian sebagai berikut:

$$
\begin{array}{ll}
65 \%-100 \% & =\text { tergolong baik } \\
35 \%-65 \% & =\text { tergolong cukup } \\
20 \%-35 \% & =\text { tergolong kurang }
\end{array}
$$

Kurang dari $20 \%=$ tergolong tidak baik

Untuk mengetahui efektif dan tidaknya Pengaruh Kompetensi Paedagogik Guru Terhadap Prestasi Belajar Siswa Kelas XI Mata Pelajaran PAI Di SMKN 13 Malang maka penulis menggunakan rumus "uji t" yaitu:

\section{Teknik Analisa uji t (Test "T")}

$$
\mathrm{Mx}=\frac{\sum x}{N_{x}}
$$

a. Mencari mean variabel $\mathrm{X}$, dengan rumus:

$$
\text { My }=\frac{\sum y}{N_{y}}
$$

b. Mencari mean variabel $\mathrm{Y}$, dengan rumus:

$x=\mathrm{X}-\mathrm{M} x$

c. Mencari deviasi standar Variabel $\mathrm{X}$ dengan rumus:

d. Mencari deviasi standar Variabel Y dengan rumus:

$y=\mathrm{Y}-\mathrm{M} y$

jumlah $x$ atau $\sum_{x}$ harus sama dengan nol.

e. Menguadratkan $x$ lalu dijumlahkan; diperoleh $\sum x_{2}$

f. Menguadratkan $y$ lalu dijumlahkan; diperoleh $\sum y^{2}$

g. Mencari

$$
t_{0}=\frac{M x-M y}{\sqrt{\frac{\left(\sum x^{2}+\sum y^{2}\right)}{\left(N_{x}+N_{y}\right)} \frac{\left(N_{1}+N_{2}\right)}{\left(N_{1} \cdot N_{2}\right)}}}
$$

\section{Paparan Dan Pembahasan Data Hasil Penelitian}

Setelah dilakukan analisis masing- masing variabel, yaitu variable $\mathrm{X}$ (Kompetensi Paedagogik Guru) dan variable Y (Prestasi Belajar Siswa), dapat diketahui bahwa variabel $\mathrm{X}$ berdistribusi normal dan variabel $\mathrm{Y}$ berdistribusi normal. Maka langkah selanjutnya adalah membuat analisis hubungan variabel $\mathrm{X}$ terhadap Y dengan membuat rank spearman. 
ANALISIS HUBUNGAN VARIABEL X TERHADAP Y

Mengurut nilai Variabel X dan Variabel Y

Tabel 4.9

\begin{tabular}{|l|l|l|l|l|}
\hline No & $\begin{array}{l}\text { No. } \\
\text { Urut }\end{array}$ & $\mathbf{X}$ & $\begin{array}{l}\text { No. } \\
\text { Urut }\end{array}$ & Y \\
\hline 1 & 21 & 18 & 2 & 32 \\
\hline 2 & 24 & 18 & 16 & 32 \\
\hline 3 & 9 & 19 & 1 & 33 \\
\hline 4 & 6 & 20 & 23 & 33 \\
\hline 5 & 2 & 21 & 6 & 34 \\
\hline 6 & 18 & 21 & 15 & 34 \\
\hline 7 & 23 & 22 & 17 & 34 \\
\hline 8 & 1 & 23 & 3 & 35 \\
\hline 9 & 15 & 23 & 24 & 35 \\
\hline 10 & 12 & 24 & 4 & 36 \\
\hline 11 & 19 & 24 & 19 & 36 \\
\hline 12 & 4 & 25 & 5 & 37 \\
\hline 13 & 13 & 25 & 11 & 37 \\
\hline 14 & 17 & 26 & 18 & 37 \\
\hline 15 & 7 & 27 & 22 & 37 \\
\hline 16 & 14 & 27 & 13 & 38 \\
\hline 17 & 16 & 27 & 18 & 38 \\
\hline 18 & 10 & 28 & 10 & 39 \\
\hline 19 & 3 & 29 & 20 & 39 \\
\hline 20 & 22 & 29 & 7 & 40 \\
\hline 21 & 5 & 30 & 9 & 41 \\
\hline 22 & 20 & 30 & 14 & 41 \\
\hline 23 & 8 & 31 & 12 & 42 \\
\hline 24 & 11 & 31 & 21 & 43 \\
\hline & & & & \\
\hline
\end{tabular}

Menentukan Rank Variabel X dan Variabel Y dengan rumus :

$\mathrm{Mr}=\frac{\text { No.urut }}{\text { Banyak Nilai Kembar }}$

$R=\sqrt{M r^{2}=\frac{\left(n^{2}-1\right)}{12}}$

Ranking Variabel X

$$
\begin{aligned}
\mathrm{M}_{\mathrm{r} 18}=\frac{21+24}{2} & =22,5 \\
\mathrm{R} & =\sqrt{22,5^{2}+\frac{\left(2^{2}-1\right)}{12}}=\sqrt{506,25+0,25}=\sqrt{506,5}=22,5
\end{aligned}
$$




$$
\begin{aligned}
& \mathrm{M}_{\mathrm{r} 20}=\frac{6}{1}=6 \\
& \mathrm{R}=\sqrt{6^{2}+\frac{\left(1^{2}-1\right)}{12}}=\sqrt{36+0}=\sqrt{36}=6 \\
& \mathrm{M}_{\mathrm{r} 22}=\frac{23}{1}=23 \\
& \mathrm{R}=\sqrt{23^{2}+\frac{\left(1^{2}-1\right)}{12}}=\sqrt{529+0}=\sqrt{529}=23 \\
& \mathrm{M}_{\mathrm{r} 24}=\frac{12+19}{2}=15,5 \\
& \mathrm{R}=\sqrt{15,5^{2}+\frac{\left(2^{2}-1\right)}{12}}=\sqrt{240,25+0,25}=\sqrt{240,5}= \\
& 15,5 \\
& \mathrm{M}_{\mathrm{r} 26}=\frac{17}{1}=17 \\
& \mathrm{R}=\sqrt{17^{2}+\frac{\left(1^{2}-1\right)}{12}}=\sqrt{289+0}=\sqrt{289}=17 \\
& \mathrm{M}_{\mathrm{r} 28}=\frac{10}{1}=10 \\
& \mathrm{R}=\sqrt{10^{2}+\frac{\left(1^{2}-1\right)}{12}}=\sqrt{100+0}=\sqrt{100}=10 \\
& \mathrm{M}_{\mathrm{r} 30}=\frac{5+20}{2}=12,5 \\
& \mathrm{R}=\sqrt{12,5^{2}+\frac{\left(2^{2}-1\right)}{12}}=\sqrt{156,25+0,25}=\sqrt{156,5} \\
& =12,5
\end{aligned}
$$

Ranking Variabel Y

$$
\begin{aligned}
& \mathrm{M}_{\mathrm{r} 32}=\frac{21+16}{2}=9 \\
& \mathrm{R}=\sqrt{9^{2}+\frac{\left(2^{2}-1\right)}{12}}=\sqrt{81+0,25}=\sqrt{81,25}=9,01 \\
& \mathrm{M}_{\mathrm{r} 34}=\frac{6+15+17}{3}=12,66 \\
& \mathrm{R}=\sqrt{12,66^{2}+\frac{\left(3^{2}-1\right)}{12}}=\sqrt{160,27+0,66}=\sqrt{160,93}= \\
& 12,68=\sqrt{\frac{4+19}{2}=11,5} \\
& \mathrm{M}_{\mathrm{r} 36}=\sqrt{11,5^{2}+\frac{\left(2^{2}-1\right)}{12}}=\sqrt{132,25+0,25}=\sqrt{132,5}=11,51 \\
& \mathrm{R} \\
& \mathrm{M}_{\mathrm{r} 38}=\frac{13+18}{2}=15,5
\end{aligned}
$$




$$
\begin{aligned}
& \mathrm{R}=\sqrt{15,5^{2}+\frac{\left(2^{2}-1\right)}{12}}=\sqrt{240,25+0,25}=\sqrt{240,5}= \\
& 15,5=\frac{7}{1}=7 \\
& \mathrm{M}_{\mathrm{r} 40}=\sqrt{7^{2}+\frac{\left(1^{2}-1\right)}{12}}=\sqrt{49+0}=\sqrt{49}=7 \\
& \mathrm{R}=\frac{12}{1}=12 \\
& \mathrm{M}_{\mathrm{r} 42}=\sqrt{12^{2}+\frac{\left(1^{2}-1\right)}{12}}=\sqrt{144+0}=\sqrt{144}=12 \\
& \mathrm{R}=\sqrt{ }
\end{aligned}
$$

Mencari $\Sigma D^{2}$

Tabel 4.10

\begin{tabular}{|l|l|l|l|l|l|l|}
\hline No & X & Y & Rank X & Rank Y & $\begin{array}{l}\text { Beda } \\
(\mathrm{d})\end{array}$ & d2 \\
\hline 1 & 18 & 32 & 22,5 & 9,01 & 13,29 & 176,62 \\
\hline 2 & 18 & 32 & 22,55 & 9,01 & 13,29 & 176,62 \\
\hline 3 & 19 & 33 & 9 & 12,01 & $-3,01$ & 9,06 \\
\hline 4 & 20 & 33 & 6 & 12,01 & $-6,01$ & 36,12 \\
\hline 5 & 21 & 34 & 10,01 & 12,68 & $-2,67$ & 7,12 \\
\hline 6 & 21 & 34 & 10,01 & 12,08 & $-2,67$ & 7,12 \\
\hline 7 & 22 & 34 & 23 & 12,08 & 10,92 & 119,24 \\
\hline 8 & 23 & 35 & 8,01 & 13,5 & $-5,49$ & 30,14 \\
\hline 9 & 23 & 35 & 8,01 & 13,5 & $-5,49$ & 30,14 \\
\hline 10 & 24 & 36 & 15,5 & 11,51 & 3,99 & 15,92 \\
\hline 11 & 24 & 36 & 15,5 & 11,51 & 3,99 & 15,92 \\
\hline 12 & 25 & 37 & 8,51 & 14,04 & $-5,5$ & 30,25 \\
\hline 13 & 25 & 37 & 8,51 & 14,04 & $-5,5$ & 30,25 \\
\hline 14 & 26 & 37 & 17 & 14,04 & 2,96 & 8,76 \\
\hline 15 & 27 & 37 & 7,25 & 14,04 & $-6,79$ & 46,10 \\
\hline 16 & 27 & 38 & 7,25 & 15,5 & $-8,25$ & 68,06 \\
\hline 17 & 27 & 38 & 7,25 & 15,5 & $-8,25$ & 68,06 \\
\hline 18 & 28 & 39 & 10 & 15 & -5 & 25 \\
\hline 19 & 29 & 39 & 12,5 & 15 & $-2,5$ & 6,25 \\
\hline 20 & 29 & 40 & 12,5 & 7 & 5.5 & 30,25 \\
\hline 21 & 30 & 41 & 12,5 & 11,51 & 0,99 & 0,98 \\
\hline 22 & 30 & 41 & 12,5 & 11,51 & 0,99 & 0,98 \\
\hline 23 & 31 & 42 & 9,51 & 12 & $-2,49$ & 6,20 \\
\hline 24 & 31 & 43 & 9,51 & 21 & $-11,49$ & 132,02 \\
\hline & & & & & & 884,18 \\
\hline
\end{tabular}


Menghitung koefisien korelasi antara variable X dan variable Y (Pho Xy) dengan rumus :

$$
\begin{aligned}
\mathrm{r}_{S}=1 & -\frac{6 \Sigma \mathrm{d}^{2}}{n\left(n^{2}-1\right)} \\
& =\quad 1-\left(\frac{6.884,18}{24\left(24^{2}-1\right)}\right) \\
& =\quad 1-\left(\frac{5305,08}{24(576-1)}\right) \\
& =\quad 1-\left(\frac{5305,08}{12800}\right) \\
& =\quad 1-0,14=0,86
\end{aligned}
$$

1. Menguji hipotesis dengan langkah sebagai berikut :

a. Mencari $Z_{\text {hitung }}$ dengan rumus :

$$
Z_{\text {hitung }}=\frac{r}{\frac{1}{\sqrt{n-1}}}=\frac{0,86}{\frac{1}{\sqrt{24-1}}}=\frac{0,86}{0,20}=4,3
$$

b. Mencari harga $\mathrm{Z}$ daftar yaitu :

$$
\begin{aligned}
\mathrm{Db} & =\quad \mathrm{N}-2 \\
& =24-2 \\
& =22
\end{aligned}
$$

Dengan $\mathrm{db}=22$ pada taraf siginfikansi $5 \%$ yang akan dicari adalah $\mathrm{db} Z(0,423)$ (22) karena $\mathrm{db}$ tidak terdapat dalam tabel, maka dilakukan interpolasi sebagai berikut :

$$
\begin{aligned}
& Z(0,423)(22) \\
& Z(0,423)(22)=0,019 \\
& Z(0,423)(24)=\frac{0,019}{0,01}
\end{aligned}
$$

$$
\begin{aligned}
\mathrm{Z}(0,423)(22) & =0,019-8 / 24(0,01) \\
& =0,019-0,003 \\
& =0,01
\end{aligned}
$$

Berdasarkan perhitungan di atas diketahui bahwa nilai $\mathrm{Z}$ hitung $=4,3$ lebih besar dari $Z$ tabel 0,01 maka hipotesisnya (Ho) ditolak dan (Ha) diterima, ini berarti adanya pengaruh antara Variabel $\mathrm{X}$ dan Variabel $\mathrm{Y}$ dengan pengaruh yang signifikan.

2. Menghitung kadar pengaruh variabel $\mathrm{X}$ dan variabel $\mathrm{Y}$ dengan rumus :

$$
\begin{aligned}
\mathrm{K} & =\sqrt{1-r^{2}} \\
& =\sqrt{1-0,86^{2}} \\
& =\sqrt{1-0,7396} \\
& =\sqrt{0,2604} \\
& =0,51
\end{aligned}
$$

Dalam bentuk persentase dengan rumus :

$$
\begin{array}{rll}
\mathrm{E} & = & 100(1-\mathrm{K}) \\
& = & 100(1-0,51) \\
& = & 100(0,49)
\end{array}
$$


$=\quad 49 \%$

Berdasarkan perhitungan diatas, bahwa pengaruh kompetensi paedagogik guru terhadap prestasi belajar siswa kelas XI Mata Pelajaran PAI Di SMKN 13 Malang sebesar $49 \%$ dan sisanya $51 \%$ ditentukan oleh faktor lain.

Kesimpulannya yaitu : Pengaruh Kompetensi Paedagogik guru terhadap prestasi belajar siswa kelas XI Mata Pelajaran PAI Di SMKN 13 Malang tergolong kuat, artinya kompetensi paedagogik guru sangat mendukung terhadap prestasi belajar siswa.

\section{Kesimpulan dan Saran Simpulan}

Berdasarkan hasil penelitian penulis terhadap Pengaruh Kompetensi Paedagogik Guru terhadap prestasi belajar siswa kelas XI Mata Pelajaran PAI Di SMKN 13 Malang kepada 24 siswa sebagai responden, dapat diangkat suatu kesimpulan sebagai berikut :

1. Pengaruh Kompetensi Paedagogik Guru dapat dikategorikan baik. Kenyataan ini didasarkan pada data kuantitatif hasil angket yang diberikan kepada responden sebanyak 24 siswa kelas XI. Dari hasil perhitungan diperoleh nilai rata-ratanya 2,49 . Dengan mengacu pada rentang penjabaran nilai terendah 1,00 dan tertinggi 5,00 angka tersebut berada pada kategori tinggi, sebab berada pada rentang interval 2,5 - , 35 .

2. Prestasi belajar siswa mata pelajaran PAI di SMKN 13 Malang berdasarkan pada angket yang disebar kepada 24 siswa sebagai responden termasuk kedalam kategori baik. Kenyataan ini didasarkan pada hasil perhitungan data kuantitatif dengan nilai rata-rata sebesar 3,67. Dengan mengacu pada penjabaran nilai terendah 1,00 dan nilai tertinggi 5,00 angka tersebut berada pada kategori tinggi, karena berada pada rentang kualifikasi 3,5-4,5.

Dari hasil perhitungan koefisien korelasi antara kedua variabel, diperoleh angka korelasinya sebesar 0,86 . Kemudian dari hasil uji $Z$ hitung menunjukkan bahwa $Z$ hitung lebih besar dari $Z$ tabel yaitu 4,3 $>0,01$ dengan demikian korelasinya signifikan. Artinya bahwa variabel X (Kompetensi Paedagogik Guru) mempunyai pengaruh terhadap varibel Y (prestasi belajar siswa Mata Pelajaran PAI) pada taraf signifikansi 5\%. Ini menunjukkan pula, bahwa arah korelasinya positif . Semakin tinggi variabel X (Kompetensi Paedagogik Guru), maka akan semakin tinggi pula variabel Y (prestasi belajar siswa Mata Pelajaran PAI). Sedangkan jika dilihat dari koefisien korelasi dari kedua variabel tersebut berada pada kualifikasi cukup kuat dengan jarak interval yaitu $0,40-0,59$. Berdasarkan hasil perhitungan, maka pengaruh Kompetensi Paedagogik Guru terhadap prestasi belajar siswa kelas XI Mata Pelajaran PAI Di SMKN 13 Malang sebesar $49 \%$ sedangkan $51 \%$ faktor lain yang dapat mempengaruhi prestasi belajar perlu diteliti lebih lanjut. 


\section{Saran}

Penelitian telah dilakukan, maka dari pengalaman hasil penelitian peneliti menawarkan beberapa saran :

1. Bagi pihak sekolah, penelitian ini dapat dijadikan acuan untuk lebih mengintensifkan hubungan yang sinergis antara sekolah dengan wali murid untuk membantu siswa dalam kegiatan belajar.

2. Bagi penelitian selanjutnya, mungkin ini bisa dijadikan bahan acuan dasar tentang penelitian pola asuh dan prestasi dan diharapkan penelitian selanjutnya bisa lebih fokus dan mendalam dari penelitian ini.

\section{Daftar Rujukan}

Andrie, Winarti \& Utami. 2001. "Pola Asuh Orangtua dan Nilai-nilai Kehidupan yang Dimiliki oleh Remaja” (Fenomena: Jurnal Psiklogi, 2001)

Al-Qur'an dan terjemahannya DEPAG RI. (Semarang; Karya Toha Putra)

Arikunto Suharsimi. 2006. "Prosedur Penelitian Suatu Pendekatan Praktik". Jakarta: PT Rineka Cipta.

Arikunto Suharsimi. 2005. “Manajemen Penelitian”. Jakarta: PT Rineka Cipta

Bahri Syaiful. 1994. "Prestasi Belajar dan Kompetensi Guru". Surabaya: Usaha Nasional.

Dimyati, Mudjiono. 1997. "Belajar dan Pembelajaran”. Bandung : Penerbit Rineka Cipta.

Dhofier Zamarkasy, dkk. 1986. "Mengasuh Anak Menurut Ajaran Islam. Jakarta: UNICEF Indonesia.

Fathurrohman Pupuh, dkk. 2007. "Strategi Belajar Mengajar Melalui Penanaman Konsep Umum dan Konsep Islami." Bandung: PT Refika Aditama.

Faisal Sanapiah. 1982. "Metodologi Penelitian Pendidikan". Surabaya: Usaha Nasional.

Ghoni Djunaidi. 2009. "Metodologi Penelitian Pendidikan Pendekatan Kuantitatif. Malang: UIN-Malang Press

Gunarsa Singgih D.1976 "Psikologi Untuk Keluarga". Jakarta: BPK. Gunung Mulia.

Hawadi Reni. 2004. “Akselerasil”.Jakarta : PT Gramedia Widiasarana Indonesia.

Huda Miftahul. 2008. 'Interaksi Pendidikan 10 Cara Qur'an Mendidik Anak”. Malang: UIN-Malang Press.

Kartono Kartini dan Andari Jeny. 1998. "Hygiene Mental dan Kesehatan Mental dalam Islam”. Bandung: Mandar Maju. 

Cipta.

Margono. 2000. "Metodologi Penelitian Pendidikan". Jakarta: PT. Rineka

Muhaimin,dkk. 1996. "Strategi Belajar Mengaja". Surabaya: CV. Citra Media karya anak Bangsa.

Muhaimin. 1991. “Konsep Pendidikan Islam”. Solo: Ramadhan.

Mussen. 1994. "Perkembangan dan Kepribadian Anak". Jakarta : Arcan.

MZ Labib. 2006. "Menciptakan Keluarga Sakinah Dalam Pandangan Islam”. Surabaya: Bintang Usaha Jaya.

Notosudirjdo \& Latipun. 2005. "Kesehatan Mental: Konsep dan Penerapan”. Malang: UMM Press.

Nursisto. 2002. "Peningkatan Prestasi Belajar Menengah" . Jakarta: Insan Cendikia.

Purwanto. 2007. "Instrumen Penelitian Sosial dan Pendidikan". Yogyakarta: Pustaka Pelajar.

Poerwadarminta WJS. 1982. "Kamus Umum Bahasa Indonesia". Jakarta: Balai Pustaka.

Petranto Ira. 2009. "Rasa Percaya Diri Anak adalah Pantulan Pola Asuh Orangtuanya Buletin DWP PTRI Jenewa, on-line: http;//www.binarymoon.co.uk/2005. Jakarta: Kawan Pustaka, Akses: 11 Maret 2009.

Rakhmat Jalaludin. 1986. "Psikologi Komunikasi”. Bandung: CV. Remaja Karya.

Slameto. 1988. "Belajar dan Faktor-Faktor yang Mempengaruhinya". Jakarta: Bina Aksara.

Syah Muhibbin. 2006. "Psikologi Pendidikan". Bandung: PT Remaja Rosdakarya.

Shochib Moh. 1998. "Pola Asuh Orangtua". Jakarta: PT RINEKA CIPTA.

Soekanto Soerjono. 2004. "Sosiologi Keluarga; Ikhwal Tentang Keluarga, Remaja dan Anak". Jakarta: PT Rineka Cipta.

Subana. 2000. "Statistik Pendidikan". Bandung: CV Pustaka Setia.

Tohirin. 2005. "Psikologi Pembelajaran Agama Islam". Jakarta: PT Raja Grafindo Persada.

Walker. 1992. "Handbook of Clinical Child Psychology". Canada: A. Wiley-Inter Science Publication.

Woolfolk Anita. 2004. "Educational Psycholog". Printed in the United States of America. 